University of Nebraska - Lincoln

DigitalCommons@University of Nebraska - Lincoln

Egyptian textiles and their production: 'word' and 'object'

Centre for Textile Research

2020

Textiles from a Late Roman/Byzantine ecclesiastical centre at Abu Sha'ar, Egypt

Lise Bender Jørgensen

Norwegian University of Science and Technology in Trondheim

Follow this and additional works at: https://digitalcommons.unl.edu/egyptextiles

Part of the Africana Studies Commons, African Languages and Societies Commons, Classical Archaeology and Art History Commons, Fiber, Textile, and Weaving Arts Commons, History of Art, Architecture, and Archaeology Commons, and the History of Science, Technology, and Medicine Commons

Bender Jørgensen, Lise, "Textiles from a Late Roman/Byzantine ecclesiastical centre at Abu Sha'ar, Egypt" (2020). Egyptian textiles and their production: 'word' and 'object'. 5.

https://digitalcommons.unl.edu/egyptextiles/5

This Article is brought to you for free and open access by the Centre for Textile Research at DigitalCommons@University of Nebraska - Lincoln. It has been accepted for inclusion in Egyptian textiles and their production: 'word' and 'object' by an authorized administrator of DigitalCommons@University of Nebraska - Lincoln. 


\title{
Textiles from a Late Roman/Byzantine ecclesiastical centre at Abu Sha'ar, Egypt
}

\author{
Lise Bender Jørgensen
}

Around AD 400 a group of Christians were looking for a new home. An abandoned Roman military fort at what is now called Abu Sha'ar, c. $20 \mathrm{~km}$ north of Hurghada on the Egyptian Red Sea coast, became the answer to their prayers. ${ }^{1}$ Steven Sidebotham of the University of Delaware excavated the site in 1987-1993. ${ }^{2}$ The fort had been established in AD 309-311 to house a mounted unit, the Ala Nova Maximiana, guarding the Via Nova Hadriana. The military phase was however short-lived: the soldiers abandoned the fort before AD 40o. The new settlers turned the former military headquarters into a church, complete with a martyr's tomb, and left various inscriptions, graffiti and Christian crosses on the walls. ${ }^{3}$ According to Sidebotham's early excavation reports the Christians were monks or hermits. ${ }^{4}$ Later, he describes this later phase of Abu Sha'ar as an "ecclesiastical center". ${ }^{5}$ This is due to the find of an almost complete papyrus in the church that papyrologists Roger Bagnall and Jennifer Sheridan date to the $5^{\text {th }}$ century AD: a letter from Apollonius to Father John and his daughter Sarah, deploring the capture of his city but rejoicing in the saving of Father John and all of his dependants. ${ }^{6}$ That the dependants of Father
John included at least one woman suggests that Abu Sha'ar was a settlement of Christians rather than a monastery or, perhaps, a place of pilgrimage to the now forgotten martyr's tomb. A graffito saying "I, Andreas, traveller to India, came here..." may have been left by a pilgrim. ${ }^{7}$ It is unknown when the Christian settlement ended; supposedly this happened peacefully in the $7^{\text {th }}$ century or later, perhaps associated either with the Sassanian invasion in AD 619-629 or the Muslim conquest in AD 640/641. ${ }^{8}$

The items found during Sidebotham's excavations at Abu Sha'ar included more than 1100 textile fragments that were examined by myself (1990-1991) and A. Marion I. van Waveren (1993). ${ }^{9}$ Most of them are from the military phase, but a significant number belong to the Christian settlement. The latter came from Trenches N (kitchen), R horrea (stores), $\mathrm{R} / \mathrm{N}$ (kitchen/stores), the upper layers of $\mathrm{D}$, $\mathrm{O}$ and $\mathrm{V}$ (principia/church), T (mill/oil press), Y (street/ stores), W (north gate) and Z (store) (fig. 1). In previous presentations and publications my main focus has been on the early group; now it is time to take a closer look at the textiles of the Christian settlement.

Published in Maria Mossakowska-Gaubert, ed., Egyptian Textiles and Their Production: 'Word' and 'Object' (Hellenistic, Roman and Byzantine Periods) (Lincoln, NE: Zea Books, 2020). doi 10.32873/unl.dc.zea.1082

1. $29^{\circ} 22.125^{\prime} \mathrm{N} / 33^{\circ} 40.970^{\prime} \mathrm{E}$.

2. Sidebotham 1989, 1991, 1992, 1993, 1994a, b.

3. Sidebotham 1993, 1994a; Bagnall \& Sheridan 1994a, b.

4. Sidebotham 1992, p. 34; Sidebotham 1994a, p. 156.

5. Sidebotham 1993, p. 7; Sidebotham et al. 2008, p. 59-6o and 145-147.

6. Bagnall \& Sheridan 1994a, p. 164-166.

7. Bagnall \& Sheridan 1994b, p. 112.

8. Sidebotham 1994a, p. 156; Sidebotham et al. 2008, p. 60.

9. Bender Jørgensen 2004, 2006, 2007, 2018a, b. I examined the textiles numbered AS 1-757, van Waveren AS 758-1102. 

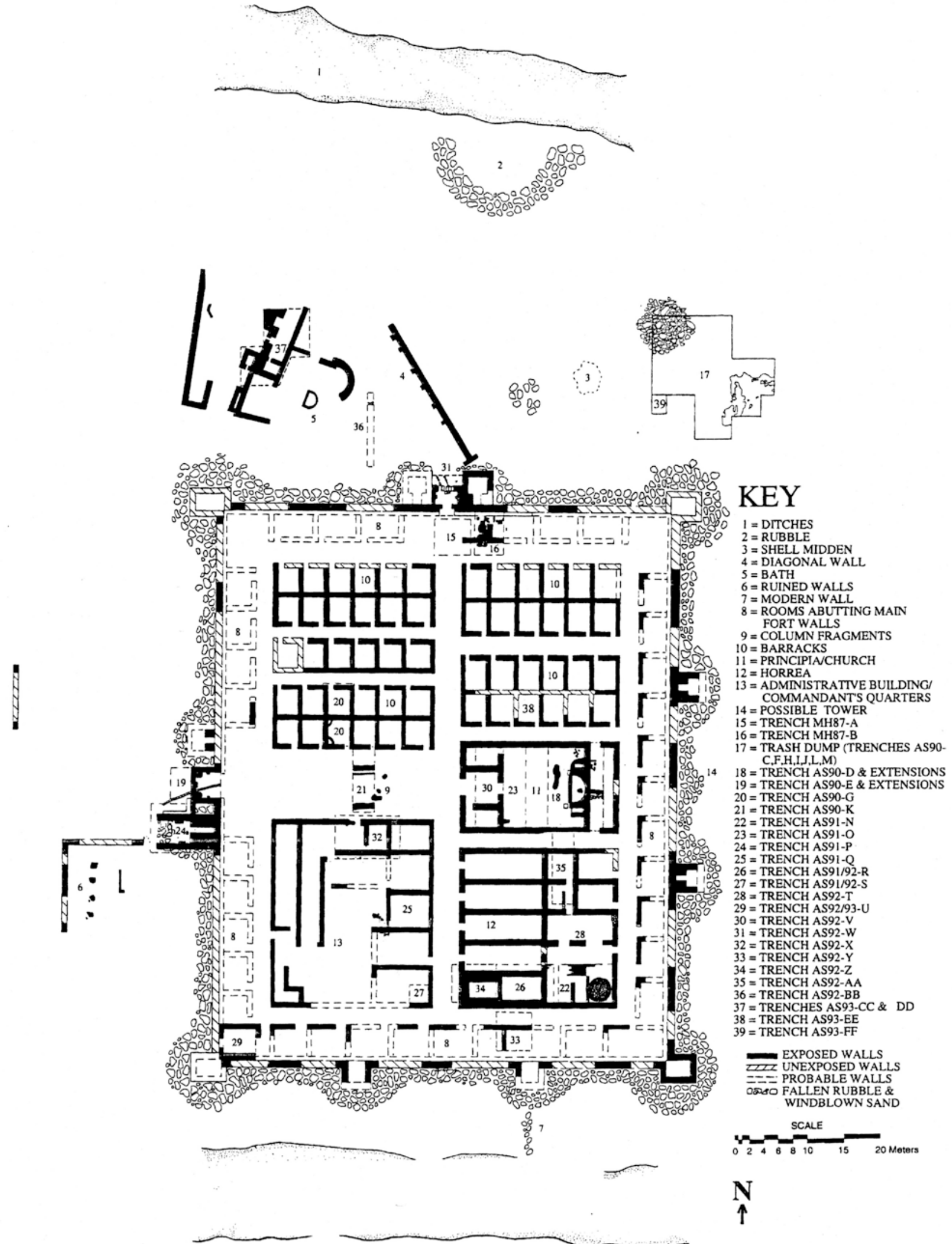

Figure 1. Plan of the fort at Abu Sha'ar with list of trenches. (Drawing (c) reproduced with permission from Steven E. Sidebotham). 


\section{Dating and phasing Abu Sha'ar}

The founding of Abu Sha'ar as a military fort in AD 309311 is documented by an inscription found at the west gate; coins and some ostraca also belong to the military phase (AS I). A Greek inscription asking the Lord Jesus Christ to save and have mercy on his servant Salamanis and the papyrus addressed to Father John are dated by their style of writing to the Christian phase (AS II). ${ }^{10}$ This also applies to a graffito of a large cross, accompanied by a prayer beseeching the god of Abraham, Isaac and Jacob, the holy god-bearer Mary, the Holy Trinity and the Lord Jesus Christ to have mercy on their worthless servant, ${ }^{11}$ and a few other texts. Except for these sources the dating and phasing of Abu Sha'ar depend on the pottery that was examined by John Riley. His report forms the basis of the phasing of the textile finds ${ }^{12}$. As regards the principia/church, this however poses some problems. Trench D (the apse area) including extensions D NEX, D SEX, D WEX produced little pottery, most of it scrappy, nonetheless Riley was able to establish two phases. The presence of Later Roman Bii amphora showed that the upper layers of these trenches belong to the Christian phase (AS II), but Riley does not supply a list of these upper layers, and textiles from Trenches D, D NEX, D SEX and D WEX therefore remain largely un-phased. Riley's catalogue does however make it possible to add textiles from D oo3 and D.S. balk to Phase II. A textile wrapped around the bones of the supposed martyr (D WEX 016) certainly belongs to the Christian phase. ${ }^{13}$ In addition, several large textile fragments, including a small tapestry found in D WEX layer 002, are also likely to belong to the Christian phase. ${ }^{14}$ According to Riley, all pottery from Trench O belongs to the military phase (AS I); the same applies to Trench V except for V 011 and V 022. Again, some exceptions can be identified. The almost complete papyrus datable to the $5^{\text {th }}$ century AD comes from Trench $\mathrm{O}$, layer $022 .{ }^{15}$ A tapestry showing a cross, found in Trench O, layer 023 must also belong to the Christian phase. ${ }^{16}$ This adds eight textiles to the 272 listed as AS Phase II in previous works. ${ }^{17}$

\section{Fibres}

Lack of laboratory facilities made it impossible to carry out formal fibre identification of the Abu Sha'ar textiles. ${ }^{18}$ Accordingly, fibres are classified according to the investigators' experience. The site's proximity to the Red Sea meant that all textiles were thoroughly impregnated with saline substances. This made them soapy to the touch and it was particularly difficult to identify the fibres. Attempts to remedy this by washing the textiles merely resulted in making them stiff and hard. The results must therefore be taken with a pinch of salt. Nonetheless c. $27 \%$ of the now 280 fragments have been categorised as wool, 54\% as flax, hemp or other bast fibre, $2 \%$ as goat hair and $7 \%$ as cotton. A few combine flax and wool, or wool and cotton. Compared with textiles from the earlier phase and with sites from the Eastern Desert of the $1^{\text {st }}$ and $2^{\text {nd }}$ centuries $\mathrm{AD}$ where wool was predominant, ${ }^{19}$ wool and bast fibres have changed places.

\section{Yarns}

A large majority of fabrics were made entirely from stwisted yarns. This applies to almost all of those made of flax or other bast fibres: only five are made of z-twisted yarns. The wool textiles show more variation: 58 are made of s-twisted yarns in both systems, three are $\mathrm{z}-\mathrm{z}$ or $\mathrm{z}-\mathrm{zz}$, seven s-z or z-s and one Z2s-s. Two goat hair fabrics are s-s, one z-z, and all cottons but two are s-s or ss-ss. Compared with the military Phase 1 , and with Mons Claudianus, ${ }^{20}$ we see a gradual increase of s-s twisted yarns while the use of z-twisted yarns dwindles.

10. Bagnall \& Sheridan 1994a, p. 159-163; Sidebotham 1994a, p. 136.

11. Bagnall \& Sheridan 1994b, p. 114.

12. Riley 1994.

13. AS 755.

14. AS 400. Depicted in fig. 31 in Bender Jørgensen 2018a and b.

15. AS91-15-3; Bagnall \& Sheridan 1994a, p. 164-166; Sidebotham 1994a, p. 141.

16. AS 649. Depicted in Sidebotham et al. 2008, pl. 6.11, and in fig. 29 in Bender Jørgensen 2018a, b.

17. Bender Jørgensen 2007, table 1; Bender Jørgensen 2018a, b, table 8.

18. Work conditions were much like those described in Bender Jørgensen \& Mannering 2001.

19. Bender Jørgensen 2004, p. 91-92; Bender Jørgensen 2006a, p. 166; Bender Jørgensen 2007, p. 28-29; Bender Jørgensen 2018a, b, fig. 43 .

20. Bender Jørgensen 2018a, b, tables 4-6 (MC) compared to tables 9-11 (AS I). 


\section{Weaves}

The weaves are mostly tabby and derivate of tabby, such as half-basket and basket weave. This applies to all fibre types. Five pieces, all of them wool, were twill. Three are densely woven $2 / 2$ diamond twills: two are plain diagonal twills. ${ }^{21}$ One piece proved to be taqueté façonné; it is also of wool. ${ }^{22}$ Five fragments with tapestries are all wool on flax. ${ }^{23}$ Two pieces are categorised as felt: ${ }^{24}$ one is wool and the other probably also wool. Compared with the military phase and other sites in the Eastern Desert we see that the number of twills has decreased. I have previously argued that twills derive from military garb. ${ }^{25}$ The presence of five twills from the Christian settlement apparently contradicts this, although as one comes from the sweep and three from top layers, they may in fact be scraps from the military phase that have been re-deposited. They may, however, also represent civilian clothing. Hero GrangerTaylor has convincingly argued that civilians as well as the military used twill cloaks for outdoor activities in the Roman world. ${ }^{26}$ Similar cloaks have continued to be in use. Several are known from the Byzantine period ${ }^{27}$ and the Berbers of North Africa still use them. ${ }^{28}$

\section{Borders and selvedges}

Edges appear in the form of four transverse borders. ${ }^{29}$ One (fig. 2) appears to be a starting border of the type associated with the warp-weighted loom. ${ }^{30}$ Three are twined or cordeline (fig. 3), and may be starting borders of the type associated with the two-beam loom, ${ }^{31}$ or corded/plaited closing borders. ${ }^{32}$ Twenty-eight simple selvedges are in bast/flax fibres, and one in cotton. Four reinforced selvedges are in wool, four in bast/flax. Those in wool are made over two or three groups of threads. ${ }^{33}$ They are often

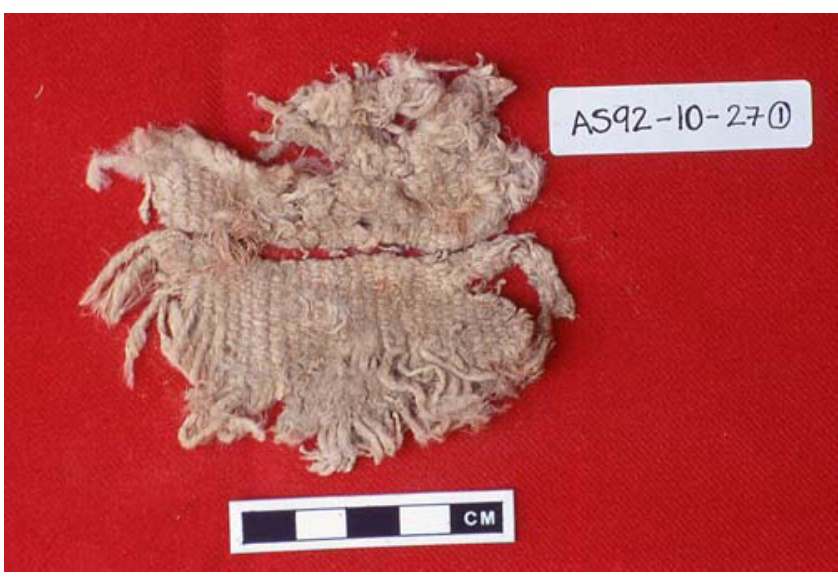

Figure 2. AS 826-827. Starting border of the type associated with the warp-weighted loom. Identified as plant fibres, probably flax. Surface find from Trench Y. (Photo (c) A. Marion I. van Waveren).

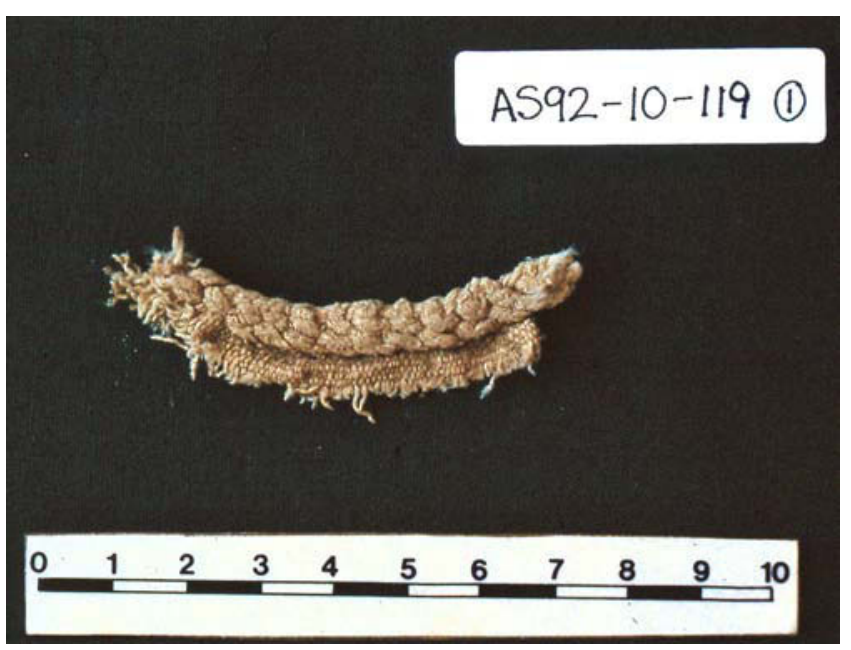

Figure 3. AS 970. Twined starting border found in Trench Z, layer 006. (Photo (C) A. Marion I. van Waveren).

21. Diamond twills AS 634, 667, 730: plain twills AS 352, 961.

22. AS 642. Depicted in fig. 28 in Bender Jørgensen 2018a, b.

23. AS 400, 649, 650, 699, 889. AS 400 is depicted in fig. 31, AS 649 in fig. 29 and AS 699 in fig. 33 in Bender Jørgensen $2018 a$, b. 24. AS $713,861$.

25. Bender Jørgensen 2004, p. 94-97; Bender Jørgensen 2006a, p. 167-171; Bender Jørgensen 2007, p. 28-29; Bender Jørgensen 2018a, chap. 47; Bender Jørgensen 2018b, chap. 46.

26. GrangerTaylor 2008, p. 12-13; see also Cardon et al. 2011, p. 319-320.

27. Granger-Taylor 2007.

28. Rabaté \& Sorber 2007, p. 55-58 and 134 .

29. AS $763,826-827,868$ and 970.

30. AS 826-27. Ciszuk \& Hammarlund 2008, p. 122-124.

31. AS 763, 868 and 970. Unfortunately, no photos exist of AS 763 and AS 868. Cf. Granger-Taylor 1982, figs. 14-15; Sheffer \& Granger-Taylor 1994, fig. 53; Ciszuk \& Hammarlund 2008, p. 124-127; for variations of these, see also Verhecken-Lammens 1993, figs. 2-11.

32. Granger-Taylor 1982, figs. 18-19; Sheffer \& Granger-Taylor 1994, figs. 13, 57; Cardon et al. 2011, fig. 304.

33. See Bender Jørgensen 2007, p. 33-34 for definitions of selvedge types. 


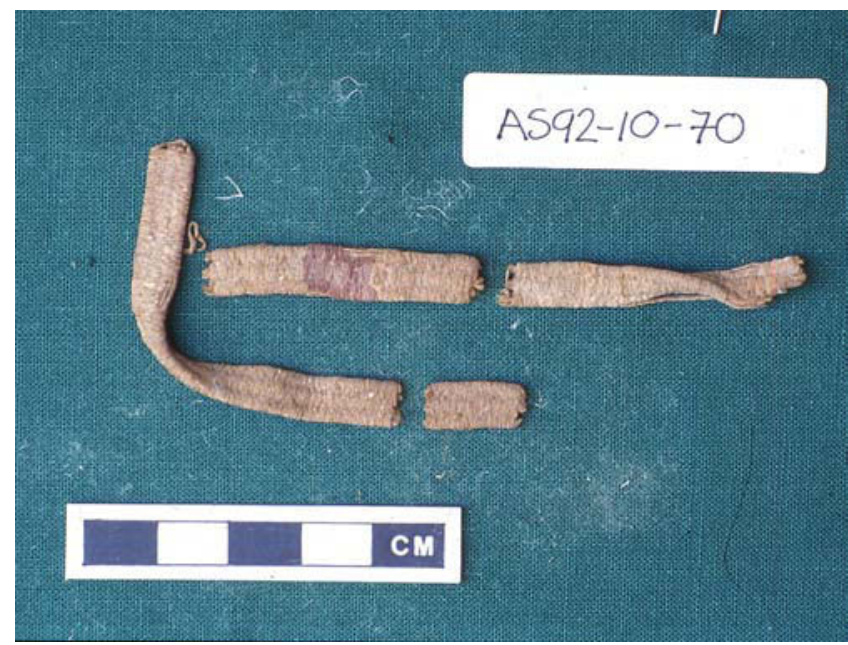

Figure 4. AS 888. Fragments of reinforced selvedge from tunic with red bands. The selvedge is torn off to be re-used as string. Surface find from Trench R at S balk. (Photo (c) A. Marion I. van Waveren).

torn off the cloth and re-used as string (fig. 4). Those of bast/flax are made with one group of threads, except one where the two outermost threads are paired. ${ }^{34}$ Compared to the military phase and to Mons Claudianus, simple selvedges are becoming more common while reinforced selvedges are getting rarer. ${ }^{35}$

\section{Decoration}

Several types of decoration were found. They consist of woven decoration such as bands, checks, self-bands and rows of twining, ${ }^{36}$ and applied decoration, such as pile. Ten textile fragments had bands; they are mainly bar bands. ${ }^{37}$ One is a pin band ${ }^{38}$ and one a composite band. ${ }^{39}$ In some cases these bands are only discernible in the torn off selvedge (fig. 4). None of the rather narrow bar bands resemble the clavi commonly found in the early sites of the Eastern

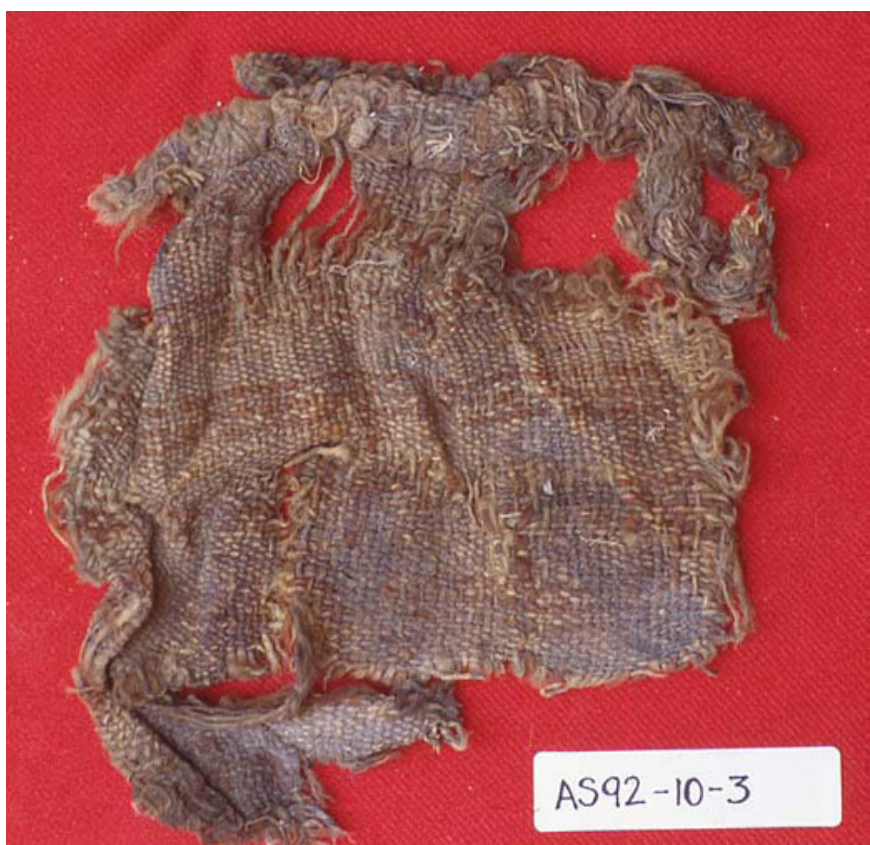

Figure 5. AS 824. Composite check. Found in Trench R, layer 048. (Photo (C) A. Marion I. van Waveren).

Desert. ${ }^{40}$ Five pieces are checked: two grid checks, ${ }^{41}$ one block check ${ }^{42}$ and two composite checks. ${ }^{43}$ The raw material of the checked fabrics is difficult to determine but it is likely to be of wool or cotton. One of the two composite checks is described by van Waveren as flax, the other as flax or cotton, but their patterns have close parallels in wool fabrics from Mons Claudianus ${ }^{44}$ and in a cotton from Berenike. 45 The Abu Sha'ar composite checks are therefore likely to be cotton or wool rather than flax (fig. 5). The grid checked pieces are similarly described as flax but more likely to be cotton. ${ }^{46}$ Both are made from s-twisted yarns; the cottons from contemporary layers at Berenike are made from z-twisted yarns and supposedly come from India. ${ }^{7}$

\section{AS 670.}

35. Bender Jørgensen 2007, p. 29; Bender Jørgensen 2018a, b, figs. 41-42.

36. For definitions, see Bender Jørgensen 2007, 2008 and 2011.

37. AS 625, 644, 672, 741, 754, 888, 931, 1040. For definitions of band types, see Bender Jørgensen 2011, p. 78.

38. As 871 .

39. AS 733 .

40. Bender Jørgensen 2007, p. 29; Bender Jørgensen 2011, p. 77-78.

41. AS 960, 975. For definitions of check types, see Bender Jørgensen 2011, p. 77-78.

42. AS 898 .

43. AS 824, 829 .

44. For example, MC 768, see Bender Jørgensen 2007, p. 32, fig. 11.

45. Wild \& Wild 2018, fig. 48.

46. AS 960 and 975. Compare AS 96o depicted in fig. 9 in Bender Jørgensen 2007 with Wild \& Wild 2018, fig. 49. 47. Wild \& Wild 2018, chap. 24. 


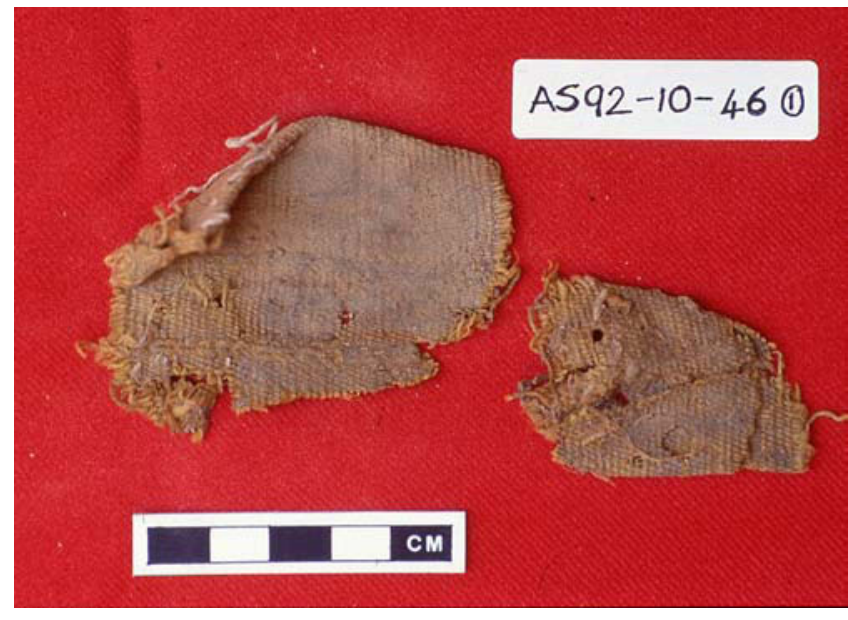

Figure 6. AS 988. Weft-faced wool tabby with two rows of twining. Found in Trench T SBEX, layer 004. (Photo (C) A. Marion I. van Waveren).

Twining was found in five pieces, all made of wool..$^{8}$ They are likely to represent the remains of tunics or cloaks, where twining was used to reinforce areas exposed to particular strain. 49 Two of them have several rows of twining, separated by a few centimetres (fig. 6). No less than sixteen pieces are decorated with self-bands, ${ }^{\circ}$ one with selfchecks. ${ }^{51}$ This stands for paired or triple threads in warp or/and weft creating subtle patterns (fig. 7). They fall in several categories but most may be characterised as SGT, Stripes through Groups of Threads. ${ }^{52}$ All of them are of flax or cotton. One of them comes from the presumed martyr's burial. This is a relatively large piece, $26 \times 22 \mathrm{~cm}$, woven in tabby with groups of triple threads in one system. The fibre is plant fibre, presumably flax; the yarns were stwisted in both systems, and the fabric had 11/12 threads per centimetre. 53

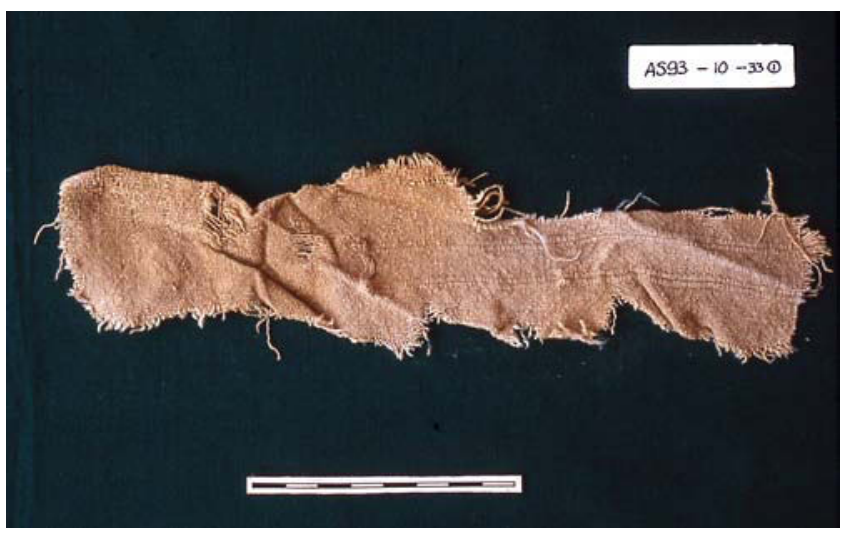

Figure 7. AS 830. Cotton or linen tabby with two rows of connected self-bands. Found in Trench R, S balk trim. (Photo (C) A. Marion I. van Waveren).

Five pieces are designated as tapestry. ${ }^{54}$ All are plain linen tabbies decorated with figured tapestry in coloured wool. The linen ground weave is made of s-twisted yarns in both systems, except in one piece 55 that has Z2s-plied warp. One is a small loose piece in green and black; the green yarn is z-twisted, the black s-twisted. It was found with large fragments of linen textile decorated with weft-float bands. ${ }^{56}$ The second, found in the church, displays a black, gem-incrusted cross, the gems in red, green and white. The black, red and green pattern wefts are z-twisted wool, while s-twisted linen yarn was used for the white ones. ${ }^{57}$ The third tapestry is a very small fragment that cannot be further described, ${ }^{58}$ while the fourth ${ }^{59}$ is obviously the decorated neckline of an under-tunic like those seen in a number of mummy portraits. ${ }^{60}$ The motif of the fifth tapestry (fig. 8) is less easy to identify. ${ }^{61}$ It may come from a tunic, or perhaps a wall hanging. The wool yarn of these last three tapestries is s-twisted. ${ }^{62}$

48. AS 578, 6o8, 613, 614, 988.

49. Granger-Taylor 1982, p. 16-18; Verhecken-Lammens 1994, p. 84-92.

50. AS 755, 772, 784, 785, 786, 812, 828, 830, 833, 841, 862, 872, 915, 923, 943, 1102.

51. AS 951.

52. For definitions of types of self-bands, see Bender Jørgensen 2008.

53. AS 755, found in Trench D WEX, layer 016. Unfortunately, no photo of this textile exists.

54. AS 400, 649, 650, 699, 889.

55. AS 650 .

56. AS 400, depicted in fig. 31 in Bender Jørgensen 2018a, b.

57. AS 649, depicted in pl. 6.11 in Sidebotham et al. 2008, and fig. 29 in Bender Jørgensen 2018 a, b.

58. As 650 .

59. AS 699, depicted in fig. 33 in Bender Jørgensen 2018a, b.

6o. Walker \& Bierbrier 1997, p. 99 and 106-107.

61. AS 889 .

62. AS 650, 699, 889. 


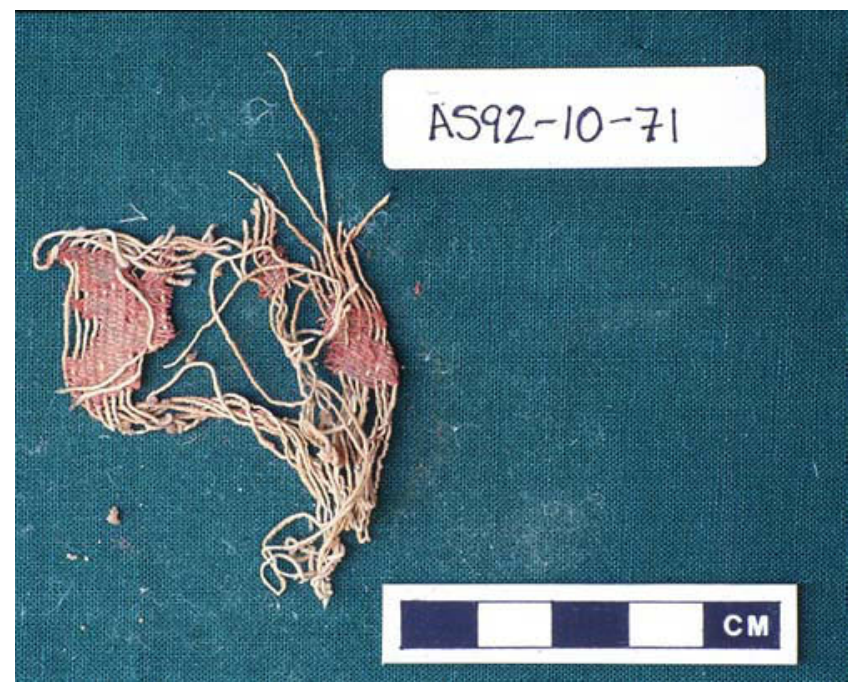

Figure 8. AS 889. Remains of figured tapestry, red wool on linen warp. Found in Trench Z, layer 002. (Photo (C) A. Marion I. van Waveren).

A fragment of a taqueté façonné was found in the horrea/ stores. ${ }^{63}$ It is of wool, $20 \times 13 \mathrm{~cm}$, made of s-twisted yarns, and the pattern has the remains of a repp border (warp: natural colour; weft: repp border blue/green, pattern: natural colour and red). Wool taquetés are well known from early Roman sites in Israel and Egypt's Eastern Desert, ${ }^{64}$ and are also found in Late Roman/Byzantine deposits at Berenike. ${ }^{65}$ The Berenike taquetés are worn on one side and are presumed to represent the remains of soft furnishings, such as cushion or mattress covers. This is also likely to be the case of the Abu Sha'ar taqueté. As shown by Martin Ciszuk, taqueté façonné can be woven on a Roman twobeam loom, entered like the zilu loom and equipped with a pattern harness. ${ }^{66}$ This, and the fact that the majority of wool taquetés have been found in Egypt leads him to argue that they were produced in specialised workshops in the Nile Valley. ${ }^{67}$

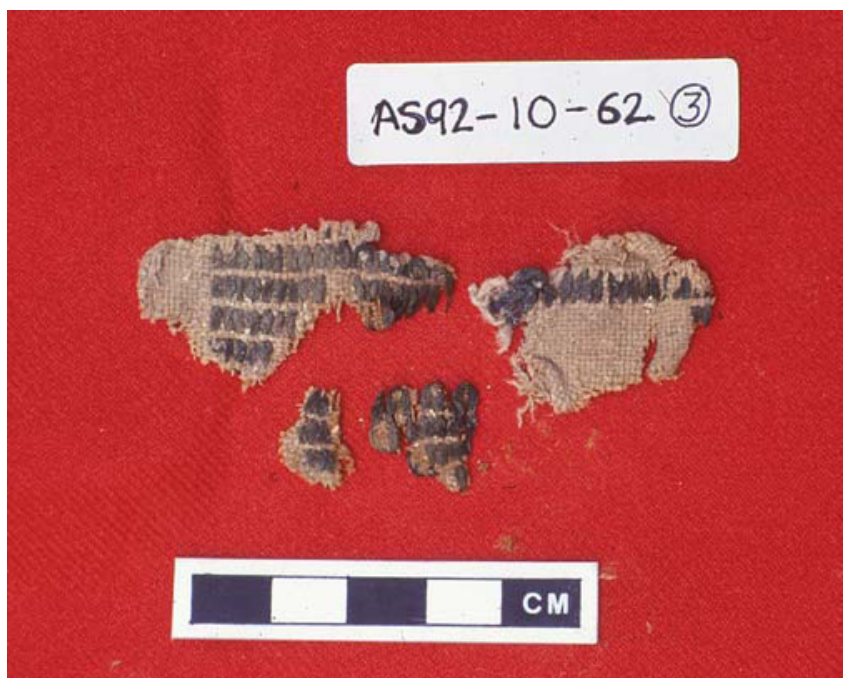

Figure 9. AS 870. Linen textile with blue-green pile. Found in Trench T WEX, layer 004. (Photo C A. Marion I. van Waveren).

Piled fabrics form a small but nonetheless important group among the textiles from Abu Sha'ar Phase II. Four piled fabrics have been recorded. ${ }^{68}$ Two are described as flax, one as cotton, one as wool. The one in cotton is in basket weave s-s, with Z2s pile. ${ }^{69}$ It ends in a hardened point that made van Waveren suggest that it could come from a loincloth. The one in wool is multi-coloured, woven in a form of tabby from S2z-plied yarns. ${ }^{70}$ One of the linens has blue-green pile in Z2s-plied yarn that is likely to be wool; ${ }^{71}$ the pile is inserted in pairs, with knots at the end (fig. 9). In another case, the pile is just a $3.8 \mathrm{~cm}$ long thread tied and ending in a knot. ${ }^{72}$ All come from the horrea/stores.

One fragment has an ink mark in the form of a rather lopsided cross in red ink (fig. 10). The textile is a tabbywoven fabric in plant fibre, possibly cotton. Both selvedges are preserved. They show that it was a narrow textile, $c$. $10 \mathrm{~cm}$ wide. This suggests that it is the remains of a sash or scarf, or perhaps leg wrappings. Another fragment appears to come from the same item. ${ }^{73}$

63. AS 642, depicted in fig. 28 in Bender Jørgensen 2018a, b.

64. Sheffer \& Granger-Taylor 1994, p. 212-215; Ciszuk 2000, 2004; Cardon 2003, p. 635.

65. Wild \& Wild 2018, chap. 20, figs. 41-42.

66. Ciszuk 2000, 2004.

67. Ciszuk 2004, p. 112-113.

68. AS 870, 880, 932, 949 .

69. AS 880 .

70. AS 949 .

71. AS 870.

72. AS 932.

73. AS 734 . 


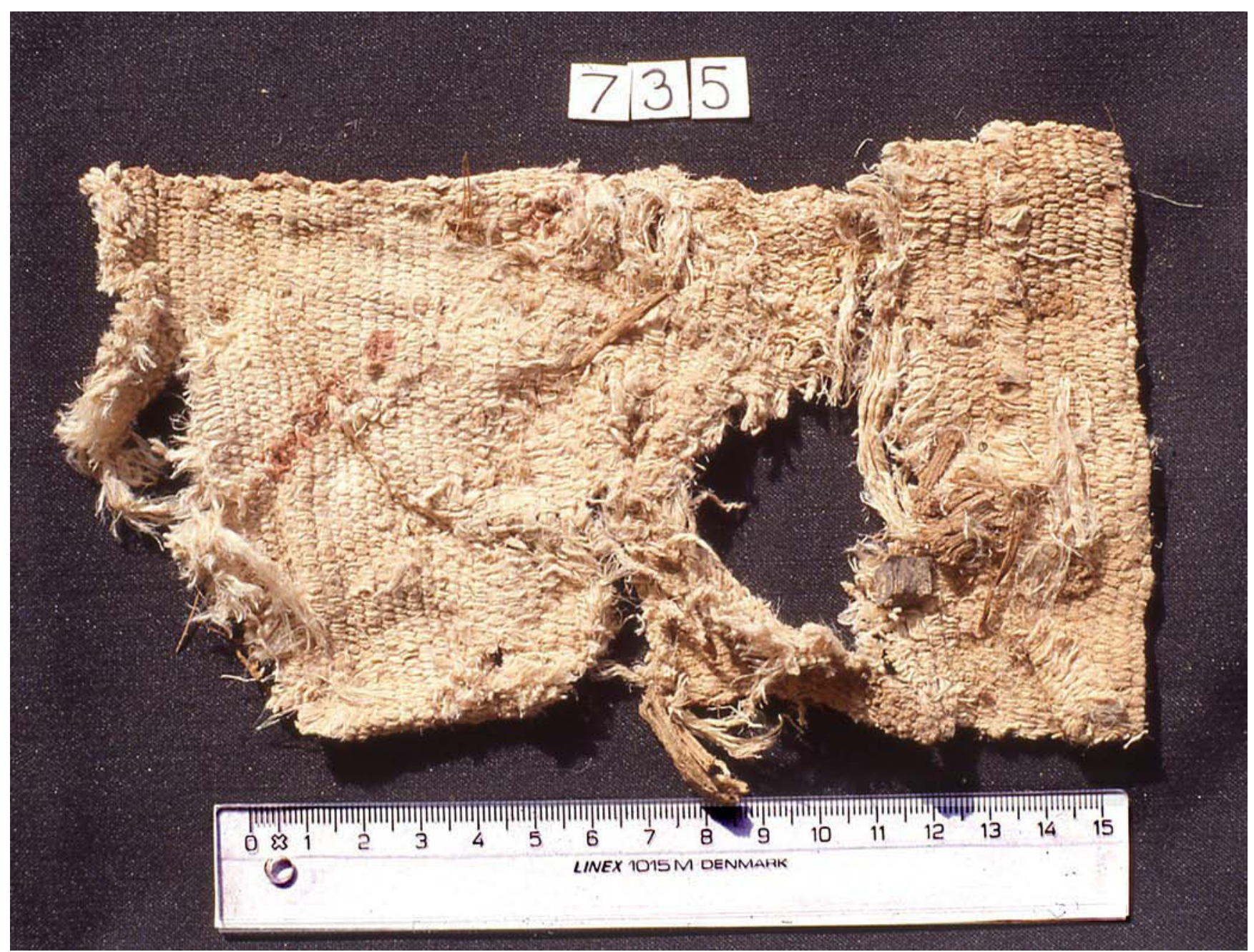

Figure 10. AS 735. Linen or cotton textile with red ink mark. Both selvedges preserved, showing it was of narrow width, c. 10 $\mathrm{cm}$. Found in Trench N, layer 020. (Photo (C) Lise Bender Jørgensen).

\section{Life and textiles at Abu Sha'ar}

Who were the people who settled in the abandoned Roman fort next to the Red Sea? The papyrus found in the church from Apollonius to Father John mentions Father John's wife, Slamo, who sends greetings to her husband and daughter. ${ }^{74}$ Slamo is a Semitic name and suggests that the family's origin was in the Sinai or Arabia. Neither the papyrologists nor the excavator is however putting any weight on this possibility. ${ }^{75}$ Instead, Sidebotham tends to suggest that they were fugitives from the Nile Valley. ${ }^{76}$ Salamanis, who beseeched Jesus Christ to have mercy on him, is likely to have come from Syria or Palestine, 77 and Andreas, who passed by on his way to India, ${ }^{78}$ are further evidence of a transient population of mixed ethnicity.

What do the textile remains tell us about these people and of their life? The 280 fragments comprise quite a wide range. They include fine, medium and coarse fabrics. Some are obviously from clothing, like the tapestry neck edging of an under-tunic. ${ }^{79}$ The reinforced selvedges of wool

74. Bagnall \& Sheridan 1994a, p. 164-166.

75. Bagnall \& Sheridan 1994a, p. 164-165; Sidebotham et al. 2008, p. 145.

76. Sidebotham et al. 2008, p. 59.

77. Bagnall \& Sheridan 1994a, p. 164.

78. Bagnall \& Sheridan 1994b, p. 112.

79. AS 699, depicted in fig. 33 in Bender Jørgensen 2018a, b. 
fabrics turned into strings for tying things up, such as the one depicted in fig. 4, are made from very fine yarns and stem from good quality tunics. The linen textile with weftfloat bands and a small tapestry is also likely to be from a tunic. $^{80}$ This may also be the case of the tapestry shown in fig. 8. The cotton with self-bands (fig. 7) may come from another tunic; the same applies to the textile wrapped around the martyr's bones. The wool fabrics with twining, such as fig. 6, may come from sleeved tunics or hooded cloaks and, as mentioned above, all the twills are presumably from cloaks.

The tapestry cross is likely to come from an altar decoration or perhaps a clerical vestment. ${ }^{81}$ Other fragments are likely to be from soft furnishings. Taquetés are, as mentioned above, usually cushion or mattress covers. A brown wool fabric with cotton stripes ${ }^{82}$ could be the remains of a coverlet, the multi-coloured piled wool fabric the remains of a rug, ${ }^{83}$ and the linen with blue-green wool pile (fig. 9) might represent a wall hanging. The fabrics with composite checks like fig. 5 have parallels among the mattresses depicted in Pompeii's brothels, ${ }^{84}$ and the worn surface of one of them suggests that the Abu Sha'ar pieces may also have been mattress covers.

Compared to the earlier, military phase of Abu Sha'ar and to other, even earlier sites in the Eastern Desert, we see a series of changes. As regards fibres, wool appears to have become less important; the use of s-twisted yarns increases. Twill is relatively frequent from the military phase and at the early Roman sites in the Eastern Desert, but does not appear much used in the Christian settlement. This, in sum, suggests that the range of textiles available to the Christian settlers was limited compared to what was available to the soldiers. They were however not without luxuries, as shown by the tapestries, the taqueté, the colourful piled rug and the possible wall hanging. Many textiles may have been hand-me-downs acquired from second-hand dealers, the centenarii, ${ }^{85}$ but other items, like the tapestry cross, must have been made for the purpose.
Did the Christians at Abu Sha'ar produce their own textiles? They were able to draw on two wells constructed by their army predecessors. ${ }^{86}$ The closest, $1 \mathrm{~km}$ away, had a pipeline leading directly to the fort. It worked under pressure, supplying up to 74 litres per minute. A second well was located $6 \mathrm{~km}$ away. This made it possible to irrigate surrounding land and grow grain and vegetables. According to Sidebotham, both water installations were in use during the Christian occupation. The wells mean that it might have been possible to cultivate flax and perhaps cotton. Sheep could have been be grazed in the neighbourhood. An amphora shoulder shard found in the baths outside the fort had an ink inscription in Greek: three words in three lines written in a hand datable to the $5^{\text {th }}-6^{\text {th }}$ centuries. According to Bagnall and Sheridan, the middle word кроки may refer to wool, or to the nap of woollen cloth. They consider it an odd word to find on an amphora but add that these jars were used for a wide variety of products. ${ }^{87}$

No textile tools were found during the excavations. The lack of spindle whorls is particularly conspicuous, although, as Grace M. Crowfoot's work on hand-spinning methods shows, whorl-less spindles can be used to make fine yarns. ${ }^{88}$ As regards looms, neither the ground loom nor the two-beam loom would have left many traces. Both are still used in Egypt and other parts of North Africa ${ }^{89}$ and some of the transverse borders found at Abu Sha'ar (fig. 3) are consistent with these loom types..$^{90}$ The warp-weighted loom may have served to produce the single item with starting borders (fig. 2), but the absence of loom weights indicates that this did not happen at Abu Sha'ar.

We may perhaps conclude that it is possible that women among the Christians, such as Father John's daughter Sarah, did produce a limited amount of textiles but it is unlikely that they could manage to make enough for everybody's needs.

80. AS 400, depicted in fig. 31 in Bender Jørgensen 2018a, b.

81. AS 649, depicted in pl. 6.11 in Sidebotham et al. 2008, and fig. 29 in Bender Jørgensen 2018a, b.

82. AS 673 .

83. AS 949 .

84. Bender Jørgensen 2011, p. 77.

85. Forbes 1964, p. 238-239; Mannering 2006, 153, Cardon et al. 2011, p. 276.

86. Sidebotham 1994, p. 263-268; Sidebotham et al. 2008, p. 317.

87. Bagnall \& Sheridan 1994b, p. 110-111.

88. Crowfoot 1931, p. 10-11, pl. 4-5.

89. Reswick 1985, p. 49-83; Picton \& Mack 1989, p. 55-67; Spring \& Hudson 1995, p. 33-38; Maurieres et al. 1996 , p. $111-112$. 9o. Ciszuk \& Hammarlund 2008, p. 120-127. 


\section{Acknowledgements}

Thanks are due to Professor Steven Sidebotham, University of Delaware, who invited me to join his excavation team at Abu Sha'ar, to Gillian Vogelsang-Eastwood for her assistance, to Hero Granger-Taylor who has always generously shared her knowledge on Roman textiles and clothing, and to A. Marion I. van Waveren who recorded the textiles from the 1992-1993 seasons and graciously handed all her documentation over to me.

\section{Bibliography}

Bagnall, R.S. \& Sheridan, J.A. (1994a) "Greek and Latin Documents from Abu Sha'ar, 1990-1991”, Journal of the American Research Center in Egypt 31, p. 159-168.

Bagnall, R.S. \& Sheridan, J.A. (1994b) "Greek and Latin Documents from Abu Sha'ar, 1992-1993”, Bulletin of the American Society of Papyrologists 31, p. 109-120.

Bender Jørgensen, L. (2004) “A Matter of Material: Changes in Textiles from Roman Sites in Egypt's Eastern Desert”, Antiquité Tardive 12, p. 87-99.

Bender Jørgensen, L. (2006) “The Late Roman Fort at Abu Sha'ar, Egypt: textiles in their archaeological context", in S. Schrenk (ed.), Textiles in situ. Their Find Spots in Egypt and Neighbouring Countries in the First Millenium CE. Riggisberger Berichte 13, p. 161-74.

Bender Jørgensen, L. (2007) "Dated Textiles from Mons Claudianus and Abu Sha'ar", in A. De Moor \& C. Fluck (eds.), Methods of Dating Ancient Textiles of the $1^{\text {st }}$ Millennium AD from Egypt and Neighbouring Countries. Proceedings of the 4th conference of the research group 'Textiles from the Nile Valley', Antwerp, 16-17 April 2005, Tielt, p. 26-35.

Bender Jørgensen, L. (2008) "Self-bands and Other Subtle Patterns in Roman textiles", in C. Alfaro \& L. Karali (eds.), Purpureae vestes II. Vestidos, textiles y tintes: estudios sobre la producción de bienes de consumo en la Antigüedad : actas del II symposium internacional sobre textiles y tintes del Mediterráneo en el mundo antiguo (Atenas, 24 al 26 de noviembre, 2005), Valencia, p. 135-142.

Bender Jørgensen, L. (2011) "Clavi and Non-clavi: Definition of Various Bands on Roman Textiles”, in C. Alfarom, Ph. Borgard, J.-P. Brun \& R. Pierobon (eds.), Purpureae Vestes III. Textiles y tintes en la ciudad antigua. Actas del III Symposium Internacional sobre Textiles y Tintes del Mediterráneo en el mundo antiguo (Nápoles, 13-15 de Noviembre, 2008), Valancia-Naples, p. 75-80.
Bender Jørgensen, L. (2018a) "Les textiles du Mons Claudianus, d'Abu Sha'ar et d'autres sites romains du désert Oriental d'Egypte”, in J.-P. Brun, T. Faucher, B. Redon \& S. Sidebotham (eds.), Le désert oriental d'Égypte durant la période gréco-romaine: bilans archéologiques. Paris. Available at: http://books. openedition.org/cdf/5168

Bender Jørgensen, L. (2018b) “Textiles from Mons Claudianus, Abu Sha'ar and Other Roman Sites in the Eastern Desert”, in J.-P. Brun, T. Faucher, B. Redon \& S. Sidebotham (eds.), The Eastern Desert of Egypt during the Greco-Roman Period: Archaeological Reports. Paris. Available at: http://books.openedition.org/cdf/5234

Bender Jørgensen, L. \& Mannering, M. (2001) “Mons Claudianus: investigating Roman textiles in the desert”, in P. Walton Rogers, L. Bender Jørgensen \& A. Rast-Eicher (eds.), The Roman Textile Industry and its Influence. A Birthday Tribute to John Peter Wild, Oxford, p. 1-11.

Cardon, D. (2003) "Chiffons dans le désert : textiles des dépotoirs de Maximianon et de Krokodilô", in H. Cuvigny (ed.), La route de Myos Hormos. L'armée romaine dans le désert oriental d'Egypte. Fouilles de l'Institut français d'archéologie orientale du Caire 48/1, Cairo, p. 619-659.

Cardon, D., Granger-Taylor, H. \& Nowik, W. (2011) "What did they look like? Fragments of Clothing Found at Didymoi: Case Studies", in H. Cuvigny (ed.), Didymoi. Une garnison romaine dans le désert Oriental d'Égypte. Fouilles de l'Institut français d'archéologie orientale du Caire 64, Cairo, p. 273-362.

Ciszuk, M. (2000) “Taquetés from Mons Claudianus: Analyses and Reconstruction", in D. Cardon \& M. Feugère (eds.), Archéologie des textiles des origines au Ve siècle. Actes du colloque de Lattes, oct. 1999. Monographies Instrumentum 14, Montagnac, p. 283-289.

Ciszuk, M. (2004) “Taqueté and Damask from Mons Claudianus: A Discussion of Roman Looms for Patterned Textiles", in C. Alfaro Giner, J.P. Wild \& B. Costa (eds.), Purpureae Vestes. Actas del I Symposium internacional sobre textiles y tintes del Mediterráneo en época roman (Ibiza, 8-10 de noviembre, 2002), Valencia, p. 107-113.

Ciszuk, M. \& Hammarlund, L. (2008) "Roman Looms A Study of Craftsmanship and Technology in the Mons Claudianus Textile Project”, in C. Alfaro \& L. Karali (eds.), Purpureae vestes II. Vestidos, textiles y tintes: estudios sobre la producción de bienes de consumo en la Antigüedad : actas del II symposium internacional 
sobre textiles y tintes del Mediterráneo en el mundo antiguo (Atenas, 24 al 26 de noviembre, 2005), Valencia, p. 119-133.

Crowfoot, G.M. (1931) Methods of Hand Spinning in Egypt and the Sudan, Halifax.

Forbes, R.J. (1964) Studies in Ancient Technology IV, Leiden.

Granger-Taylor, H. (1982) "Weaving Clothes to Shape in the Ancient World: the Tunic and Toga of the Arringatore”, Textile History 13/1, p. 3-25

Granger-Taylor, H. (2007) "Weaving Clothes to Shape in the Ancient World 25 years on: Corrections and Further Details with Particular Reference to the Cloaks from Lahun", Archaeological Textiles Newsletter 45, p. 26-35.

Granger-Taylor, H. (2008) "A Fragmentary Roman Cloak Probably of the $1^{\text {st }} \mathrm{c}$. CE and Off-cuts from Other Semicircular Cloaks", Archaeological Textiles Newsletter 46, p. 6-16.

Mannering, U. (2006) "Questions and Answers on Textiles and Their Find Spots: The Mons Claudianus Textile Project”, in S. Schrenk (ed.), Textiles in situ. Their Find Spots in Egypt and Neighbouring Countries in the First Millenium CE. Riggisberger Berichte 13, p. 149-159.

Maurieres, A., Ossart, E. \& Lapeyre, C. (1996) Au fil du désert. Tentes et tissages des pasteurs nomads de Méditerranée, Aix-en-Provence.

Picton, J. \& Mack, J. (1989) African Textiles (2 ${ }^{\text {nd }}$ edition), London.

Rabaté, M.-R. \& Sorber, F. (2007) Berber Costumes of Morocco. Traditional Patterns / Costumes berbères $d u$ Maroc. Décors traditionels, Paris.

Reswick, I. (1985) Traditional Textiles of Tunisia and related North African Weavings, Los Angeles.

Riley, J. (1994) “Abu Sha'ar Fort. The Pottery Report”. Unpublished report dated 22. November 1994.

Sheffer, A. \& Granger-Taylor, H. (1994) “Textiles from Masada. A Preliminary Selection”, in D. Barag, A. Sheffer \& K. Bernick (eds.), Masada IV. The Yigael Yadin Excavations 1963-1965. Final Reports. Jerusalem, p. 151-281.

Sidebotham, S.E. (1989) "Fieldwork on the Red Sea Coast: The 1987 Season", Journal of the American Research Center in Egypt 26, p. 127-166.

Sidebotham, S.E. (1991) "University of Delaware Archaeological Project at Abu Sha'ar: the 1990 season", Newsletter of the American Research Center in Egypt 153, p. 1-6.
Sidebotham, S.E. (1992) "The 1991 Season of Archaeological Fieldwork at Abu Sha'ar (Red Sea Coast), Egypt conducted by the University of Delaware", Archaeological News 17, Numbers 1-4, p. 31-34.

Sidebotham, S.E. (1993) "University of Delaware Archaeological Project at Abu Sha'ar: the 1992 Season", Newsletter of the American Research Center in Egypt 161/162, p. 1-9.

Sidebotham, S.E. (1994a) "Preliminary Report on the 1990-1991 Seasons of Fieldwork at Abu Sha'ar (Red Sea Coast)", Journal of the American Research Center in Egypt 31, p. 133-158.

Sidebotham, S.E. (1994b) "University of Delaware Fieldwork in the Eastern Desert of Egypt, 1993”, Dumbarton Oaks Papers 48, p. 263-275.

Sidebotham, S.E., Hense, M. \& Nouwens, H.M. (2008) The Red Land. The Illustrated Archaeology of Egypt's Eastern Desert, Cairo - New York.

Spring, C. \& Hudson, J. (1995) North African Textiles, London.

Verhecken-Lammens, C. (1993) “Opzetboorden bij koptische weefsels”, Vlaamse Vereniging voor oud en hedendags textiel Bulletin 1992, p. 29-36.

Verhecken-Lammens, C. (1994) “Two Coptic Wool Tunics in the Collection of the Abegg-Stiftung: A Detailed Analysis of the Weave Techniques Used", Riggisberger Berichte 2, p. 73-103.

Walker, S. \& Bierbrier, M. (1997) Ancient Faces. Mummy Portraits from Roman Egypt, London.

Wild, F. \& Wild, J.P. (2018) "Contrastes textiles à Bérénice”, in J.-P. Brun, T. Faucher, B. Redon \& S. Sidebotham (eds.), Le désert oriental d'Égypte durant la période gréco-romaine : bilans archéologiques, Paris. Available at: http://books. openedition.org/cdf/51651. 